\title{
THE UNEXPLORED ROLES OF PROBIOTIC BACTERIA: IN VITRO ANTI-INFLAMMATORY AND ANTHELMINTIC ACTIVITY OF ENTEROCOCCUS FAECIUM BM10 KY788342 AND LACTOBACILLUS CASEI GM10 KY794586
}

\author{
NEHA JAIN*, ARCHANA MEHTA \\ Department of Botany, Laboratory of Molecular Biology, Dr. H. S. Gour Central University, Sagar - 470 003, Madhya Pradesh, India. \\ Email: nehaj147@gmail.com
}

Received: 26 April 2017, Revised and Accepted: 20 May 2017

\section{ABSTRACT}

Objective: The aim of the present study was to evaluate the in vitro anti-inflammation activity and anthelmintic potential of two novel isolated probiotic strains through Enterococcus faecium BM10 KY788342 and Lactobacillus casei GM10 KY794586.

Methods: In vitro anti-inflammatory activity was evaluated using protein denaturation inhibition method. Pheretima posthuma was used as a suitable in vitro model, and time of paralysis and death were used as parameters to evaluate anthelmintic potential of probiotic strains.

Results: Lyophilized solutions of $L$. casei GM10 showed significant protein denaturation inhibition $(56.20 \pm 0.86 \%)$ followed by E. faecium BM10 $(52.28 \pm 0.31 \%)$ comparable to diclofenac $(93.62 \pm 1.39 \%)$ at the maximum concentration of $250 \mu \mathrm{g} / \mathrm{ml}$. Intracellular cell-free extract of E. faecium BM10 showed a strong anthelmintic (vermicidal) activity ( $6 \pm 0.23$ minutes), followed by L. casei GM10 ( $9 \pm 0.05$ minutes) comparable to piperazine citrate $(20 \pm 0.422$ minutes) and albendazole ( $24 \pm 0.43$ minutes) at the maximum concentration of $100 \mathrm{mg} / \mathrm{ml}$.

Conclusion: Results of the present study concluded that both tested lactic acid bacteria strains exhibited significant in vitro anti-inflammatory activity and can be used as potent and safe anthelmintic agent.

Keywords: Lactic acid bacteria, Anti-inflammatory, Anthelmintic, Intracellular cell-free extract.

(C) 2017 The Authors. Published by Innovare Academic Sciences Pvt Ltd. This is an open access article under the CC BY license (http://creativecommons. org/licenses/by/4. 0/) DOI: http://dx.doi.org/10.22159/ajpcr.2017.v10i9.19413

\section{INTRODUCTION}

Intestinal inflammation and infections are generally accompanied due to an imbalance of intestinal microflora. Probiotic bacteria play an important role in balancing the gut natural microflora and now used as the alternative approach of prevention and therapy for numerous intestinal inflammatory disorders, including inflammatory bowel disease. The mechanisms associated with probiotics include blocking of pathogenic bacterial effects by producing antibacterial compounds; competitive inhibition of pathogens and toxins from adhesion to intestinal epithelium; regulate mucosal immune response through improving intestinal immunological barrier (mainly IgA response), enhancing host innate immunity; and maintain a control between proand anti-inflammatory cytokines [1,2]. Furthermore, Lactobacillus rhamnosus GG MTCC 1408 and lyophilized cell-free supernatant of Enterococcus faecium CFR 3003 exhibited a strong anti-inflammatory effects by downregulating the tumor necrosis factor (TNF) - a production and increasing the IL-10 levels in lipopolysaccharidestimulated macrophage cell lines [3].

Helminthic infections are generally caused by soil-transmitted helminths. These infections are common in those areas where inadequate sanitation and unsafe water supplies are prevalent. These parasitic worms also infect livestock and crops. According to latest estimates, more than 2 billion people are infected with these parasites [4]. Although many synthetic drugs including preparation, benzimidazole, imidazothiazole, and albendazole are available in the market, and in addition to it, various herbal plant parts also utilized as an anthelmintic agent, but these synthetic drugs are losing their effectiveness as resistance develops in nematodes against drugs [5]. Only a few studies have been conducted regarding the use of bacterial metabolites as anthelmintic [6-8], therefore in the present study, two probiotic strains: E. faecium BM10 KY788342 and Lactobacillus casei GM10 KY794586 evaluated for anthelmintic activity and antiinflammatory activity.

\section{METHODS}

In vitro anti-inflammatory activity

In vitro anti-inflammatory activity was performed using protein denaturation inhibition assay [9]. Reaction mixture $(0.5 \mathrm{ml})$ contains $0.45 \mathrm{ml}$ of bovine serum albumin (BSA) $(5 \% \mathrm{w} / \mathrm{v}$ aqueous solution) and $0.05 \mathrm{ml}$ of lyophilized lactic acid bacteria (LAB) test sample (50,100, and $250 \mu \mathrm{g} / \mathrm{ml})$ in citrate buffer. Test control solution $(0.5 \mathrm{ml})$ comprised $0.45 \mathrm{ml}$ of BSA $(5 \% \mathrm{w} / \mathrm{v}$ aqueous solution) and $0.05 \mathrm{ml}$ of distilled water, whereas product control solution $(0.5 \mathrm{ml})$ consisted of $0.45 \mathrm{ml}$ of distilled water and $0.05 \mathrm{ml}$ of test solution $(50,100$, and $250 \mu \mathrm{g} / \mathrm{ml})$. Standard solution $(0.5 \mathrm{ml})$ prepared by $0.45 \mathrm{ml}$ of BSA ( $5 \% \mathrm{w} / \mathrm{v}$ aqueous solution) and $0.05 \mathrm{ml}$ of diclofenac sodium $(50,100$, and $250 \mu \mathrm{g} / \mathrm{ml})$. $\mathrm{pH}$ of all solutions adjusted to 6.5 . The samples were incubated at $37^{\circ} \mathrm{C}$ for 20 minutes, and then the temperature was increased to $57^{\circ} \mathrm{C}$ for 3 minutes. After cooling, $2.5 \mathrm{ml}$ of phosphate buffer saline was added to the above solutions. The absorbance was measured at $416 \mathrm{~nm}$. The percentage inhibition of protein denaturation was calculated as

Protein denaturation inhibition $(\%)=\left(\mathrm{OD}_{\mathrm{t}} / \mathrm{OD}_{\mathrm{c}}-1\right) \times 100$

\section{Anthelmintic activity}

Preparation of intracellular cell-free extract (ICFE)

ICFE of both LAB was prepared according to the study by Chen et al. [10]. $10 \mu \mathrm{l}$ of LAB culture was inoculated in $250 \mathrm{ml}$ of De Man-Rogosa Sharpe broth medium and incubated for 3 days at $30^{\circ} \mathrm{C}$. The bacterial counts in the cell suspension (intact cells) were adjusted to $10^{8} \mathrm{cfu} / \mathrm{ml}$. The cell suspensions were subjected to ultrasonic disruption (five 1-min intervals in an ice bath), the cell debris was removed by centrifugation 
$(10,000 \times \mathrm{g})$ for 10 minutes at $4^{\circ} \mathrm{C}$, and the prepared resulting supernatant (ICFE) was collected and used for the study.

\section{Procedure}

Anthelmintic activity was carried out according to the method suggested by Bharti et al. [11]. Indian adult earthworms (Pheretima posthuma) were used for the study as these have anatomical and physiological resembles with intestinal roundworm parasites of human being. Earthworms were collected from moist soil and washed with normal saline and used for the study. The ICFE of both bacteria were dissolved in $20 \mathrm{~mm}$ citrate phosphate buffer and prepared desired concentrations $(25,50$, and $100 \mathrm{mg} / \mathrm{ml})$. Piperazine citrate and albendazole were used as the standard drugs. 13 groups containing 6 earthworms in each group were placed in petri dishes containing $15 \mathrm{ml}$ test and standard formulation. Group 1 served as control $(0.9 \% \mathrm{NaCl})$, Groups 2, 3, and 4 treated with piperazine citrate $(25,50$, and $100 \mathrm{mg} / \mathrm{ml})$, Groups 5, 6, and 7 treated with albendazole $(25,50$, and $100 \mathrm{mg} / \mathrm{ml})$, Groups 8,9 , and 10 treated with ICFE of E. faecium GM10 (25, 50, and $100 \mathrm{mg} / \mathrm{ml})$, and Groups 11,12 , and 13 treated with ICFE of L. casei GM10 (25, 50, and $100 \mathrm{mg} / \mathrm{ml}$ ). Observations were made for the time taken for paralysis and death of individual worm. The paralysis was assumed to occur when the worms were not able to move even in normal saline while the death was concluded when the worms lost their motility followed with fading away from their body colors. Assay was conducted in triplicates.

\section{RESULTS}

\section{Anti-inflammatory activity}

In the present study, in vitro anti-inflammatory activity of a lyophilized solution of E. faecium BM10 and L. casei GM10 was determined by percentage inhibition of protein denaturation method and compared with standard drug Diclofenac. E. faecium BM10 showed protein denaturation inhibition (\%) $45.10 \pm 0.16,49.58 \pm 0.50$, and $52.28 \pm 0.31$ at the concentration of 50,100 , and $250 \mu \mathrm{g} / \mathrm{ml}$, respectively. However, L. casei GM10 exhibited protein denaturation inhibition (\%) $48.15 \pm 1.78$, $51.34 \pm 1.80$, and $56.20 \pm 0.86$ at the concentration of 50,100 , and $250 \mu \mathrm{g} / \mathrm{ml}$, respectively. The standard drug Diclofenac showed protein denaturation inhibition (\%) $88.02 \pm 0.98,90.11 \pm 1.06$, and $93.62 \pm 1.39$ at the concentration of 50,100, and $250 \mu \mathrm{g} / \mathrm{ml}$ (Fig. 1). Both LAB strains showed concentration-dependent inhibition of protein denaturation, and L. casei GM10 considered being a stronger anti-inflammatory agent than E. faecium BM10.

\section{Anthelmintic activity}

In the present investigation, ICFEs of E. faecium BM10 and L. casei GM10 were tested for anthelmintic activity using Pheretima posthuma model, and the results were compared with standard drugs: Piperazine citrate and albendazole. The LAB strains and standard drugs showed concentration-dependent anthelmintic activity. The paralysis (vermifuge) and death time (vermicidal) of ICFE of $E$. faecium BM10 were $6 \pm 0.029$ minutes, $4 \pm 0.017$ minutes, and $3 \pm 0.10$ minutes and $10 \pm 0.16$ minutes, $9 \pm 0.32$ minutes, and $6 \pm 0.23$ minutes at the concentration of 25,50 , and $100 \mathrm{mg} / \mathrm{ml}$, respectively. However, the paralysis and death time of ICFE of $L$. casei GM10 were $11 \pm 0.71$ minutes, $9 \pm 0.34$ minutes, and $6 \pm 0.03$ minutes and $18 \pm 0.48$ minutes, $15 \pm 0.22$ minutes, and $9 \pm 0.05$ minutes at the concentration of 25,50 , and $100 \mathrm{mg} / \mathrm{ml}$, respectively. The paralysis and death time of worms showed by standard drug piperazine citrate were $30 \pm 0.87$ minutes, $21 \pm 0.61$ minutes, and $14 \pm 0.30$ minutes and $42 \pm 1.03$ minutes, $35 \pm 0.35$ minutes, and $20 \pm 0.422$ minutes at the concentration of 25,50 , and $100 \mathrm{mg} / \mathrm{ml}$, respectively. The paralysis and death time of worms showed by albendazole were $35 \pm 0.76$ minutes, $27 \pm 0.23$ minutes, and $18 \pm 0.92$ minutes and $50 \pm 1.57$ minutes, $40 \pm 0.88$ minutes, and $24 \pm 0.43$ minutes at the concentration of 25,50 , and $100 \mathrm{mg} / \mathrm{ml}$, respectively. The maximum anthelmintic activity was showed by ICFE of E. faecium BM10 and minimum by albendazole (Fig. 2).

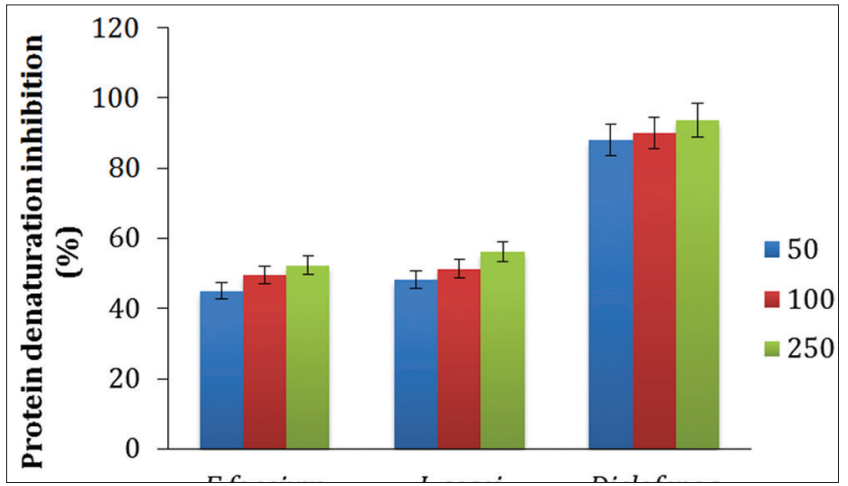

Fig. 1: Anti-inflammatory activity (\%) of Enterococcus faecium BM10 and Lactobacillus casei GM10 compared to diclofenac (standard drug)

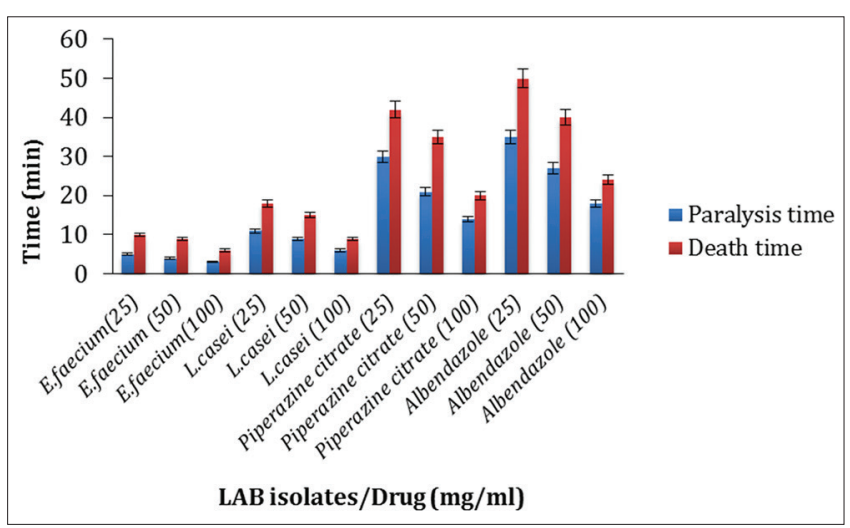

Fig. 2: Anthelmintic activity of Enterococcus faecium BM10 and Lactobacillus casei GM10 compared to standard drugs (piperazine citrate and albendazole)

\section{DISCUSSION}

Denaturation of tissue proteins is a well-documented cause of inflammation [12] and arthritic disease. The inflammatory drugs (salicylic acid, phenylbutazone, etc.,) have shown dose-dependent ability to thermally induced protein denaturation [13]. It has been reported that one of the features of several non-steroidal anti-inflammatory drugs is their ability to stabilize (prevent denaturation) heat-treated albumin at the physiological $\mathrm{pH}$ (pH: 6.2-6.5). Results of anti-inflammatory activity revealed that E. faecium BM10 and L. casei GM10 decrease protein denaturation significantly. Recently, Williams et al. [14] demonstrated that $L$. reuteri BM36301 suppressed TNF- $\alpha$ induction and decreased inflammation in aged mice. Similarly, Carroll et al. [15] investigated the anti-inflammatory role of $\mathrm{MnSO}_{4}$ released from Lactobacillus gasseri in interleukin 10-deficient colitis mouse. Mostly previously reported anti-inflammatory activities were assessing medicinal herbs as antiinflammatory agents $[16,17]$. Our study first time reported the in vitro anti-inflammatory activity of probiotic strains and exhibited significant results of anti-inflammatory activity.

'Avermectin' a series of compounds contains high degree of anthelmintic and anti-parasitic activity, isolated from Streptomyces avermitilis, and many metabolites have been isolated from bacteria (Brevibacillus laterosporus strain G4 and Bacillus sp. B16) and fungi (Arthrobotrys oligospora, Cylindrocarpon destructans, Verticillium chlamydosporium, and Paecilomyces lilacinus) also showed antinematode activity [18-20]. Our study showed strong anthelmintic activity of ICFE of both tested LAB strains (E. faecium BM10 and L. casei GM10) and considered more effective than piperazine citrate and albendazole. Similar results also 
reported by Bharti et al., [11] L. plantarum and L. acidophilus exhibited $100 \%$ paralysis of worms within $48 \mathrm{hrs}$. Extract containing metabolites of Bacillus cereus and Bacillus pumilus also showed significant anthelmintic activity in paralyzing the worms. Probiotic bacteria have a symbiotic relation in the human gut and tested LAB strains showed good acid and bile salt tolerance activity in the previous reported study, therefore our study to assess the anthelmintic activity based on the fact that the LAB strain can kill intestinal worms without affecting natural gut balance and would not show any resistance in anthelmintic due to having human origin.

\section{CONCLUSION}

In vitro anti-inflammatory activity and anthelmintic activity of tested strains are the novel studies employed for assessing therapeutic applications of E. faecium BM10 and L. casei GM10 strains. Lyophilized LAB solution of tested strains showed significant anti-inflammatory activity as well as ICFE of both tested probiotic strains exhibited potent anthelmintic activity. In vitro studies are the first step to assess any microbe or compound for their therapeutic potential followed by in vivo activities. Significant findings of in vitro assay assured and forced for conducting in vivo activities, and future studies of tested LAB strains will be carried out in this direction.

\section{ACKNOWLEDGMENT}

The authors would like to express their grateful to the Department of Botany, Dr. H. S. Gour (Central) University, Sagar (M.P.), for providing necessary facilities to carry out this work and also thanking full to the DST INSPIRE, for providing a grant for this work.

\section{REFERENCES}

1. Ménard S, Candalh C, Bambou JC, Terpend K, Cerf-Bensussan N, Heyman M. Lactic acid bacteria secrete metabolites retaining anti-inflammatory properties after intestinal transport. Gut 2004;53(6):821-8.

2. Amdekar S, Roy P, Singh V, Kumar A, Singh R, Sharma P. Antiinflammatory activity of Lactobacillus on carrageenan-induced paw edema in male wistar rats. Int J Inflam 2012;2012:752015.

3. Divyashri G, Krishna G, Muralidhara, Prapulla SG. Probiotic attributes, antioxidant, anti-inflammatory and neuromodulatory effects of Enterococcus faecium CFR 3003: In vitro and in vivo evidence. J Med Microbiol 2015;64(12):1527-40.

4. World Health Organization. Soil-Transmitted Helminthiases: Eliminating Soil-Transmitted Helmnthiases as a Public Health Problem in Children. Progress Report; 2012. p. 1-90.

5. Holden-Dye L, Robert WJ. Anthelmintic drugs and nematicides: Studies in Caenorhabditis elegans. In: Worm Book: The Online Review of C. Elegans Biology. New York, USA: W. H Freeman; 2013. p. 1-22.
6. Kumar ML, Thippeswamy B, Kuppust IL, Naveenkumar KJ, Shivakumar CK. Evaluation of Bacillus cereus and Bacillus pumilus metabolites for anthelmintic activity. Pharmacognosy Res 2015;7(1):81-4.

7. Haber CL, Heckaman CL, Li GP, Thompson DP, Whaley HA, Wiley VH. Development of a mechanism of action-based screen for anthelmintic microbial metabolites with avermectinlike activity and isolation of milbemycin-producing Streptomyces strains. Antimicrob Agents Chemother 1991;35(9):1811-7.

8. Amanto JS, Brooklyn NY, Cvetovich R, Scotch, P. United States Patent No. 19; 1995.

9. Kar B, Nepal A, Kumar RB, Dolai N, Bhattacharya S, Upal K, et al. Antioxidant and anti-inflammatory properties hymenodictyon excelsum bark. Orient Pharm Exp Med 2013;13(2):103-11.

10. Chen Q, Kong B, Sun Q, Dong F, Liu Q. Antioxidant potential of a unique LAB culture isolated from Harbin dry sausage: In vitro and in a sausage model. Meat Sci 2015;110:180-8.

11. Bharti V, Mehta A, Jain N, Singh S, Ahirwal L. In vivo acute toxicity, antibacterial, antiaquatic fungal, antihelminthic activity of Lactobacillus plantarum kp894100 and Lactobacillus acidophilus. Asian J Pharm Clin Res 2016;9(1):1-5.

12. Opie EL. On the relation of necrosis and inflammation to denaturation of proteins. J Exp Med 1962;115(3):597-608.

13. Mizushima Y, Kobayashi M. Interaction of anti-inflammatory drugs with serum proteins, especially with some biologically active proteins. J Pharm Pharmacol 1968;20(3):169-73.

14. Williams LA, Connar AO, Latore L, Dennis O, Ringer S, Whittaker JA, et al. The in vitro anti-denaturation effects induced by natural products and non-steroidal compounds in heat treated (immunogenic) bovine serum albumin is proposed as a screening assay for the detection of anti-inflammatory compounds, without the use of anim. West Indian Med J 2008;57(4):327-31.

15. Carroll IM, Andrus JM, Bruno-Bárcena JM, Klaenhammer TR, Hassan HM, Threadgill DS. Anti-inflammatory properties of Lactobacillus gasseri expressing manganese superoxide dismutase using the interleukin 10-deficient mouse model of colitis. Am J Physiol Gastrointest Liver Physiol 2007;293(4):G729-38.

16. Saraswathi R, Upadhyay L, Venkatakrishnan R, Meera R, Devi P. Phytochemical investigation, analgesic and anti-inflammatory activity of Abutilon indicum Linn. Int J Pharm Pharm Sci 2011;3:154-6.

17. Nagore DH, Ghose VK, Patil MJ, Wahile AM. In vitro antioxidant and in vivo anti-inflammatory activity of Cassia sophera Linn. Int J Pharm Pharm Sci 2010;2:113-21.

18. Giblin-Davis RM, Williams DS, Bekal S, Dickson DW, Brito JA, Becker JO, et al. 'Candidatus pasteuria usgae' sp. Nov. An obligate endoparasite of the phytoparasitic nematode Belonolaimus longicaudatus. Int J Syst Evol Microbiol 2003;53:197-200.

19. Dash GK, Suresh P, Sahu SK, Kar DM, Ganapaty S, Panda SB. Evaluation of Evolvulus alsinoides Linn. For anthelmintic and antimicrobial activities. J Nat Rem 2002;2(2):182-5.

20. Partap S, Kumar S, Kumar A, Sharma NK, Jha KK. In-vitro anthelmintic activity of Luffa cylindrica leaves in Indian adult earthworm. J Pharmacogn Phytochem 2012;1(2):27-30. 